\title{
Triangular Policy Inference from Renewable Energy, Foreign Direct Investment (FDI) and Urbanization Towards Climate Goal: Insight from Indonesia
}

Edmund Ntom Udemba ( $\sim$ eudemba@gelisim.edu.tr)

Gelisim University: Istanbul Gelisim Universitesi

Lucy Davou Philip

Eastern Mediterranean University: Dogu Akdeniz Universitesi

\section{Research Article}

Keywords: Economic growth (GDP), FDI, urbanization, carbon neutrality, sustainable study, Indonesia

Posted Date: September 17th, 2021

DOl: https://doi.org/10.21203/rs.3.rs-803937/v1

License: (c) (1) This work is licensed under a Creative Commons Attribution 4.0 International License.

Read Full License 
Triangular policy inference from renewable energy, Foreign Direct Investment (FDI) and Urbanization towards climate goal: Insight from Indonesia

Edmund Ntom Udemba ${ }^{1}$

Lucy Davou Philip ${ }^{2}$

1. Faculty of Economics Administrative and Social sciences

Istanbul Gelisim University, Istanbul-Turkey

Email: eudemba@gelisim.edu.tr; eddy.ntom@gmail.com

Tel: +905357808713; WhatsApp: +2347039678122

8

2. Department of Economics

Eastern Mediterranean University,

P.O. Box 99628 via Mersin 10,

Famagusta, North Cyprus, Turkey.

lucychoji@yahoo.com

\section{Funding}

Authors declare non-funding for this present research

\section{Compliance with Ethical Standards}

Authors declare no conflicts of interest at any level of this study.

\section{Acknowledgements}

Our manuscript has not been received or subjected to review at another journal or other publishing outlets

\section{Abstract}

This is an expository study towards ascertaining the ability of Indonesia in mitigating carbon emission. Indonesia is positioned as among the best performing economies in Southeast Asia because of its vigorous fiscal management and sustained economic growth over the years. The country's foreign investment inflow increased to $14 \%$ in 2019 , largely in gas, electricity, water, and transportation because of the viability of its macroeconomic reforms. To test the environmental implication of this macroeconomic performance of Indonesia and to see its ability to achieve carbon neutrality, we adopt Indonesian quarterly data of 1990Q1- 2018Q4 for empirical analysis. Relevance Instruments in the economic performance of Indonesia such as urbanization, 
31 foreign direct investment (FDI) and renewable energy source are all adopted for accurate 32 estimations and analysis of this topic. Different approaches such as structural break test, autoregressive distributed lag (ARDL)-bounds testing and granger causality are all adopted in this

34 study. Our analysis and policy recommendations are based on short run and long run ARDL 35 dynamics and granger causality. Findings from ARDL confirmed, negative relationship between carbon emission and renewable energy source, FDI and urbanization. Also, a U-shape instead of inverted U-shape EKC is found confirming the impeding implication of Indonesian economic growth to its environmental performance if not checkmate. From granger causality analysis, all the variables are seen transmitting to urbanization in a one-way causal relationship. Also, FDI and renewable energy prove to be essential determinants of the country's environment development, hence, FDI is seen transmitting to both energy source (fossil fuels and renewables) in a one- way causal relationship. Renewable energy is as well seen having two ways causal relationship with both carbon emission and fossil fuels. This result has equally exposed the significant position of 44 the three instruments (urbanization, FDI and renewable energy source) in Indonesia environment development.

Keywords: Economic growth (GDP); FDI; urbanization; carbon neutrality; sustainable study;

47 Indonesia

Highlights of Indonesia's environment performance

1. This is a time series study of Indonesia's environmental performance

2. Renewable energy, urbanization and foreign Direct Investment (FDI) are used to assess the possibility of accessing carbon neutrality in Indonesian

3. Indonesia's ambition towards mitigating carbon emission is confirmed with the three 


\section{Introduction}

61 Fiscal direct investment (FDI) is a crucial microeconomic and macroeconomic tool for both 62 developing and emerging economies. A robust FDI regime has the propensity to engender higher63 income generation, spur job creation opportunities (reduce unemployment) and can enhance 64 diversification. For instance, Indonesia is regarded as one of the largest economy in Southeast Asia because of its vigorous fiscal management and sustained economic growth over the years. Through structural reforms, the country's foreign investment increased to $14 \%$ in 2019 , largely in gas,

67 electricity, water, and transportation. The Indonesian government implemented policies that have contributed to their growth in investment mainly on tax incentives for investment in major economic sectors, law enforcement and business certainty, cuts in interest rate tax on exporters and energy tariffs for industries. These policies have qualified Indonesia to rank as the 17th out of 20 top host countries based on the source of investment. Japan is the largest and the USA is the 5th source of investment. (World investment report 2020).

FDI has declined from the year 2020 mainly due to the uncertainty over the development of the covid-19 pandemic which has adversely lead to the world economic decline. The fall in foreign investment was more in the developed economies, fall by $69 \%$ reported by UNCTAD (UNCTAD 2021). The flows of FDI to the United States indicated a decline mostly in the primary sector with $49 \%$, making the foreign investors discrete with their capital to productive assets. Furthermore, the uncertainty affects the flow of FDI to developing economies as well with a $12 \%$ fall in FDI inflow, reported with a fall of $-4 \%$ in Asia, $-18 \%$ in Africa, $-37 \%$ in Latin America and the Caribbean. However, despite the pandemic, Indonesia is expecting more investment in 2021. The government has approached bona fide companies to invest in the country. According to the investment coordinating Board (bkpm) indicates the growth of investment in Indonesia despite the pandemic in 2020 . The foreign investment grew to $2.1 \%$ (US\$58.8 billion), $1.11 \%$ higher than the target. Domestic investment increased by $7 \%$, while foreign direct investment reduced by $2.4 \%$ (Rahman Dzulfigar 2021).

Notwithstanding the significance of FDI in promoting growth, it also has disadvantages. It can act

87 as a monopoly which will affect the domestic markets. Foreign Investment has improved its 88 benefits globally as well as in Indonesia over the last decades. FDI flows have influence economic 
growth in Indonesia positively. Many researches have proved its benefits on how foreign investment added value to both foreign investors and domestic (local) firms. To improve an economy's production capacity through FDI flows, improve the quality of export and barriers should be minimized or removed to enhance competition (Khaliq and Noy 2007; Sjoholm F 2017). Correspondingly, policies should be enforced to lighten tariff and labour market arrangements because excessive tariff on imported inputs by host country discourages multinational firms thereby leading to a reduction in FDI inflow (Ahmad et al 2018). Khaliq and Noy (2007) increase in FDI improves the economic growth of Indonesia. Show that the impact of FDI on the non-oil and gas industry, electricity and water, retail and wholesale trade, transport and communications, hotels and restaurant, all have positive impact on the economy. However, FDI impact on mining and quarrying reduces economic growth. Katircioglu (2009), Mahmood and Mahmood (2016), and Effendi and Soemantri (2003) asserted that not all sectors benefit from foreign investment which indicates that more attention should be given to sectors that contribute to economic growth. However, other studies believe it does not affect economic growth (Kersan-Skabic and Zubin (2009).

With the rising flows of FDI into the Indonesian economy, moreover, it will be instructive to 105 explore the major impact of the rise in FDI inflows on the environmental sustainability of the nation. Many studies have confirmed the positive influence of FDI on environmental quality (Udemba E. 2019, Haug and Ucal (2019), Sarkodie and Strezov (2019).

Philip et al (2021) analyzed the cause of foreign direct investment, urbanization, income, and energy used on the Turkish environment amid the global economic plunge. Indicated that all the variables contribute to environmental degradation in Turkey. Suggested that policies should be fixed on green investment inflow and encourage the use of renewable energy. Jun et al (2018) analyzed the impacts of FDI and economic growth on pollution applied the wavelet tool from 1982-2016. Their findings confirm that foreign investment positively impacts environmental degradation indicating that an increase in FDI increases emissions both in the short-run and long run in China. Abdouli and Hammami (2017) indicated a rise in foreign investment and income increases pollution. The study of Sasana, Sugiharti and Setyaningsih (2018) staes that high economic growth in Indonesia reduces environmental degradation. While foreign investments 
have a positive impact on $\mathrm{CO} 2$ emissions showing that the activities of the multinational companies reduce the quality of the environment.

However, others indicate that FDI reduces CO2 emissions (Shahbaz et al 2019, Joshua, Bekun, Sarkodie 2020). Atici C (2012) found no evidence that FDI influences CO2 emission negatively showing that foreign investment in ASEAN economies does not lead to increasing pollution due to operating in nonpolluting sectors. Merican et al (2007) test the impact of FDI on the environment of these developing countries Indonesia, Malaysia, Singapore, Thailand, and Philippines. Employing the Autoregressive Distributive Lag (ARDL) model and found that the inflow of FDI increases environmental degradation in Thailand, Malaysia, and Philippines, whereas increase in foreign investment decreases environmental pollution in Indonesia and shows insignificant relation in Singapore. Bachri and Normelani (2020) evaluate the nexus of disposable income and environmental degradation on FDI in Indonesia utilized the ARDL and Granger Causality test from 1960-2018. Revealed that FDI have a significant impact on environmental pollution and income.

According to World Resources Institution (WRI), Indonesia is the 5th largest emitter of greenhouse gasses in the world due to the transmutation of carbon-rich sources, ecological and social reactions. The Indonesia Administration decided to reduce greenhouse gas emissions to the minimum of 26 percent by 2020 and 41 percent with financial support from developed countries. Also, plan to minimize emissions by 2030 to below $662 \mathrm{MtCo} 2 \mathrm{e}$ through the reduction of forest debasement to attain the nation's target of environmental sustainability (World Bank Country Director for Indonesia). Indonesia has notable fossil fuel types include oil, coal and natural gas, and renewable energy resources. In 2013 Indonesia became the largest exporter of coal (IEA 2014). However, it generates power from renewable energy (solar, wind, hydro, and geothermal of 788, 00 megawatts of power. Sasana and Ghozali indicated that subsidies on fossil fuel enhance the increase of emissions which reduce the environmental quality of Indonesia.

Renewable energy is an important source of energy. It minimizes the effect of greenhouse gas emissions (types of air pollution) by reducing the use of fossil fuels (coal, gas, oil). Also, important because it reduces the dependence on imported fuels, creates economic development, jobs in manufacturing and installation. The problems or challenges that slow the development of renewable energy in Indonesia are policy uncertainty, financing barriers, low renewables 
manufacturing volume, and market barriers (IRENA 2017). Sugiawan and Managi (2016) investigate the EKC and the impact of foreign direct investment, energy production from renewable energy sources, on environmental pollution in Indonesia. The outcome of the analysis reveals the insignificant support for $\mathrm{EKC}$, and energy production increases the level of $\mathrm{CO} 2$ emissions in the period of the study. On the contrary, renewable energy have a significant and beneficial influence in the reduction of environmental pollution. Finally, an increase in the total factor of productivity decreases emissions both periods. Recommended that decrease in subsidies on fossil fuels should be encourage to minimize the use of fossil fuel for electricity consumption, in return for renewable energy consumption by providing incentives for more efficient and cleaner technologies to enhance Indonesia's electricity generation. Shezan et al (2017) reveal that hybrid system is significantly favorable to the environment by reducing the effect of $\mathrm{CO} 2$ emissions in Indonesia. Recommended cost reduction and suitable control systems for hybrid energy system, also maximize the available renewable energy sources. Indeed, studies by Viccakusumadewi and Limmeechokchai (2017) for Indonesia and Thailand, Qi et al (2014) for China, Sebri and BenSalha (2014) for BRICS, confirm that increase in renewable energy use reduces the effect of CO2 emissions.

Urbanization in Indonesia has increased over the years just like any other country. Jakarta is the largest city in Indonesia which is the nation's capital with about 10 million populations (Aaron O'Neil 2021). People move from rural to urban areas for job opportunities, good health care, social benefits and services. The urban area creates more opportunities for innovation, industrialization and commercialization. Apart from these rural-urban movement benefits, it also has its negative side such as dismantling of habitats and increase environmental pollution. Some researchers analysed the impact of urbanization on economic growth and environmental sustainability. The study of Sasana et al (2019) states that an increase in the population of urban areas increases investment activities through the use of higher oil fuel which later enhances the rates of $\mathrm{CO} 2$ emissions. This indicates that urbanization activities may have a positive influence on environmental pollution by increasing pollution in urban areas. Ali et al (2019) proved that urbanization influences emissions. Government policies are needed for green technology to control pollution from industrial and residential areas. Anwar et al (2020) stated the increase in urbanization and economic growth has increase pollution in East Asia. Encourages sustainable urbanization and the use of green resources to stimulate economic stability without impacting the 
environment negatively. Nonetheless, the environmental effect on both the present and future growth of Indonesia is of great importance to policymakers. According to United Nations sustainable development goals (SDGs), individual countries are encouraged to work towards curtailing climate change by maintaining good environmental quality through carbon neutrality.

To this end, the present study seeks to analyze the possibility of accessing carbon neutrality with the nexus of FDI, renewable energy, urbanization in Indonesia This defines the objective of this study which is to investigate the possibility of the officials of Indonesia to mitigate carbon emission with the three policies (FDI, renewable energy and urbanization) to enhance carbon neutrality of the country. For clear insight to this subject, authors aim to examine the empirical evidence of the impact of FDI inflows and renewable energy on the environmental quality of Indonesia by employing approaches (such as structural break; bound cointegration test and symmetric ARDL dynamics model). Studies have been made for the case of Indonesian environmental performance but the uniqueness of this work is the combination of three dominating and paramount economic features (FDI, renewable energy and urbanization) of the country to survey its sustainability and carbon management. Our study will add to the literature through the revealing power of the three policies in curtailing emission rate and fostering carbon neutrality in Indonesia.

The rest part of this study are; section 2-theoretical background, section 3-methodology, modelling and date, section 4-empirical results and discussion, section 5-concluding remarks.

\section{Theoretical Background}

The present study is anchored on the transformed version of IPAT (STIRPAT) model according to Dietz and Rosa (1994). IPAT model (Erhlin and Holdren, 1970) gives insight on the environmental impact of human agents which are most times measured with three basic instruments (population, wealth and technology). This model was first developed in the 1970s with hypothesis of environmental effects from the three factors. The assertion of IPAT model is the multiplicative power of the instruments (population, wealth and tech) in determining the environment without the individual ability of each variable in determining the environment. The conventional IPAT model takes the form:

$$
I=P A T
$$


Where I denotes carbon emission which represents environment, $\mathrm{P}$ denotes population, A denotes wealth which is represented with real GDP per capita and T denotes technology.

After a while, changes were observed and made in IPAT model because of its shortcomings. IPAT was later transformed into STIRPAT model by Dietz and Rosa (1994) to have a mathematical identical by showing the stochastic impacts of the instruments through regression. This accommodates application of quadratic or other polynomial style of wealth (GDP) in testing EKC hypothesis. STIRPAT model has the capacity to test the empirical analysis of the impacts of the instruments on the environment. This can be done on individual bases by controlling other variables while testing the effect of one instrument on the environment. Also, environmental Kuznets curve (EKC) was adopted as among the theories in this study. EKC hypothesis as developed by Simon Kuznets, (1955) was intended to test the income inequality and was later adopted by some environment economies to test the effect of income (GDP) growth on weather development. The underline part of EKC hypothesis is turning point that exists between income (GDP) growth and environment. It is assumed that the initial stage of economic growth will undermine the atmosphere condition till it gets to a certain point where the impact will turn to positive on environment. Different shapes (U- shape, N-shape and inverted U-shape) are expected to exist depending on the interaction of economic growth and environment.

\section{Methodology, Modeling and Data}

Our study is modelled according to the extended version of IPAT (STIRPAT) and ARDL-bound testing. IPAT was first introduced by Ehrlic and Holdren, (1970) for the analysis of human impact on environment. Following the introduction of this model, some scholars (Harrison, 1994; York et al., 2002) adopted this model for analysis of human factors in determining the environment condition. Three instruments (population, affluence and technology) were adopted according to Ehrlic and Holdren to expose the part played by human agents in shaping the quality of environment. In attempt to include statistical testing and inference in the IPAT theory, Dietz and Rosa, $(1994,1998)$ expanded IPAT to STIRPAT. The latest version of IPAT (STIRPAT) explains the stochastic involvement of human agents in environment development through population, affluence and technology. Asides from suitability of STIRPAT model in empirical and hypothesis testing, it also allows the expansion of the model to include other regressors (York et al., 2003a,b) and their functional forms such as quadratic or other polynomial version apart from the three basic 
237 instruments in the model. Hence, EKC hypothesis and other explanatory variables are all 238 accommodated in STIRPAT model. STIRPAT is modelled as follows:

$239 \quad I=\alpha P^{b} A^{c} T^{d} e$

240 From Equation 1, $\alpha$ is the constant while b, $\mathrm{c}$ and $\mathrm{d}$ are the exponents of the instruments (P, A and

$241 \mathrm{~T})$ to be estimated. e is the error term. The logarithmic form of equation 1 is as follows:

242

$l I=a+b l P+c l A+d l T+e$

243 Part of the properties ( $a, b, c, d$ and e) of equation 2 have been defined in equation 1. Specifically, $244 \mathrm{a}, \mathrm{b}, \mathrm{c}$ and $\mathrm{d}$ in equation 2 are the coefficients of the instruments (population, affluence and 245 technology). The coefficients explains the level of change that existed in the dependent variable ( 246 I) due to the percentage change in the explanatory variables ( $\mathrm{P}, \mathrm{A}$ and $\mathrm{T})$. As remarked in the above, 247 the ability of STIRPAT to accommodate other instruments apart from the three basic instruments 248 and equally accommodate the quadratic form of the instruments, this present study includes other 249 sensitive instruments that are important in studying Indonesia environment performance. Hence, FDI, renewable and non-renewable energies and GDP². Scholars like Zhang and Zhao, 2019 and Guo et al., 2019 have utilized the expanded form of STIRPAT with inclusion of other variables.

252 We also adopt urban population as proxy to population, GDP per capita (constant, 2010) as proxy 253 to affluence and FDI as proxy to technology. We adopt FDI in place of technology in this study 254 because of its multifaceted position in both economic growth and environmental performance 255 through direct and indirect effects. Through FDI, direction effect of technology is possible through 256 introduction of innovated technologies via importation by the foreign companies. This could be 257 inform of bringing in new and enhanced carbon mitigating machines and transferring of expatriate 258 into the host economies. Also, the indirect effect of FDI is possible through spillover effect such 259 transferring the skills and knowledge of the foreign expatriates to the local actors in manufacturing sectors. This has significant effect both on the economic and environment performance, hence, 261 creating room for economies of scale and job opportunities, and moderation of the emission and 262 pollution rate due to the newly introduced innovated technologies. Other Scholars (Hubler and 263 Keller 2010; Javorick and Spatareanu, 2008; Keller, 2004) have equally adopted FDI in place of 264 technology in determining environmental performance. Therefore, the expanded STIRPAT model 265 with inclusion of all the instruments in this study is as follow: 
$l C O_{2}=a_{o}+a_{1} l U . P+a_{2} l Y+a_{3} l Y^{2}+a_{4} F D I+a_{5} l F o s s+a_{6} l R . E+a_{7} D U M 1+$

$a_{8} D U M 2+e$

Where $l C O_{2}, l U . P, l Y, l Y^{2}, F D I, l F o s s, l R . E, D U M 1, D U M 1$ and $e$ denote carbon dioxide emission, urban population, GDP per capita and its squared (constant, 2010), foreign direct investment (\%GDP), non-renewable energy consumption as proxy by fossil fuels (I.e. summation of crude oil, natural gas and coal in millions tonnes oil equivalent), renewable energy consumption (million tonnes of oil equivalent), dummy variables for structural break and the error term. All the variables except FDI are all expressed in natural logarithm. The variables except environment indicators (carbon emission, fossil fuels and renewable energy) are all sourced from 2018 updated World Bank Development Indicators (WDI). All the environment indicators are sourced from 2019 British Petroleum World Energy statistics. Considering the objective of this study, that is, assessing carbon neutrality of Indonesia with the selected variables (renewable energy, FDI and urbanization), we adopted carbo dioxide emission $\left(\mathrm{CO}_{2}\right)$ as the best indicator for measuring the environment. Carbon emission tends to be major contributor to the greenhouse gas emission with almost 76 percent of the gas Intergovernmental Panel on Climate Change, (IPCC, 2014). Indonesia case is unique with FDI and renewable energy consumption showing evidence of mitigating carbon emission in most some studies (Udemba et al., 2019 for Indonesia). Indonesian quarterly data of 1990Q1- 2018Q4 are utilized in this study. Instrument and their measurements are defined and summarized in Table 1 below. Also, the trend of the adopted instruments of this study is displayed in Figure 1.

Moreover, we further the modelling of this present study to ascertain the existence of cointegration. We modelled this with Autoregressive Distributed Lag (ARDL)-bound testing. ARDL-bound approach is preferred to other approaches in cointegration estimates (Pesaran et al., 2001). Part of the advantages of ARDL - bound testing over other approaches is ability to accommodate multiple forms of integrations among the series. Accommodation of the sample size irrespective of the size is part of the advantages of ARDL. No stringent condition before the adoption of ARDL except the avoidance of second order of integration I(2). Following this, we modelled the cointegration according to the ARDL-bound testing with inclusion of both short run and long run estimates with error correction model (ECM) as follow: 
$\Delta l C O_{2 t}=b_{0}+b_{1} l C O_{2 t-1}+b_{2} l U . P_{t-1}+b_{3} l Y_{t-1}+b_{4} l Y_{t-1}^{2}+b_{5} F^{2} I_{t-1}+b_{6} l F O S S_{t-1}+$

$$
b_{7} l R . E_{t-1}+b_{8} l D u m 1_{t-1}+b_{9} l D u m 2_{t-1} \quad \sum_{i=0}^{s-1} \emptyset_{1} \Delta l C O_{2 t-i}+\sum_{i=0}^{t-1} \emptyset_{2} \Delta l U . P_{t-i}+
$$

$\sum_{i=0}^{t-1} \emptyset_{3} \Delta l Y_{t-i}+\sum_{i=0}^{t-1} \emptyset_{4} \Delta l Y_{t-1}^{2}+\sum_{i=0}^{t-1} \emptyset_{5} \Delta F D I_{t-i}+\sum_{i=0}^{t-1} \emptyset_{6} \Delta l F O S S_{t-i}+$

$\sum_{i=0}^{t-1} \emptyset_{7} \Delta l R . E_{t-i}+\sum_{i=0}^{t-1} \emptyset_{8} \Delta l D u m 1_{t-i}+\sum_{i=0}^{t-1} \emptyset_{9} \Delta l D u m 2_{t-i}+E C M_{t-i}+\varepsilon_{t}$

299

300

301

302

303

304

305

306

307

308

309

310

311

312

313

314

From Equation 4, some of the properties and the instruments (carbon emissions, urban population, GDP per capita, squared GDP per capita, FDI, Foss, renewable energy and Dum) have been defined from other equations $1 \rightarrow 3$. The remaining properties such as $b_{i}, \emptyset_{i}$ ( $\mathrm{i}=1,2$.etc.), $\sum, \Delta$ and $E C M_{t-i}$ are coefficients of long run $\left(b_{i}\right)$ and short run $\left(\emptyset_{i}\right)$, summation of short run and differenced form of the instruments $\left(\sum, \Delta\right)$, and the error correction model $\left(E C M_{t-i}\right)$. From the ARDL -bound testing model, cointegration is estimated by comparing the values of $F$ and $T$ stats with the critical values of upper bounds. Hence, if the values of the F and T-stats are greater than the critical values of the upper bound test at 1,5 and 10 percent significant values, it is concluded that cointegration exist and vice versa. If the values of $\mathrm{F}$ and $\mathrm{T}$-stats fall in between the the upper and lower bounds, the outcome is said to be inconclusive. This analysis is anchored on a hypothetical statements against or in support of the existence of cointegration. The null hypothesis is against the existence of cointegration, while the alternative hypothesis is in support of the existence of cointegration. The two hypotheses are expressed as follows: Null hypothesis $\left(\mathrm{H}_{0}\right): b_{i}=0$ and the alternative hypothesis $\left(\mathrm{H}_{1}\right): b_{i} \neq 0$.

Table 1: Summary of the instruments

\begin{tabular}{llll}
\hline Numbers & Variables & Short form & Definition/Measurements \\
\hline 1 & Carbon & $\mathrm{CO}_{2}$ & Carbon Dioxide Emission in million tonnes of \\
emission & & carbon dioxide, in natural log and retrieved from \\
& & 2019 British Petroleum World Energy statistics
\end{tabular}

2

$$
\text { GDP per capita Y }
$$

3

$\begin{array}{lll}4 & \text { Urban } \\ \text { Population } & \text { U.P } \\ 5 & \end{array}$

Squared GDP $\quad \mathrm{Y}^{2}$ per capita
Economic growth proxy by Gross Domestic Product(GDP) per capita (constant, 2010), in natural $\log$ and retrieved from 2018 updated WDI

Economic growth proxy by Gross Domestic Product(GDP) per capita (constant, 2010), in natural $\log$ and retrieved from 2018 updated WDI Urban population in natural $\log$ and retrieved from 2018 updated WDI 


\begin{tabular}{llll}
\hline Fossil fuels & Foss & $\begin{array}{l}\text { Non-renewable (Fossil fuels) consumption in natural } \\
\text { log and retrieved from 2018 updated WDI }\end{array}$ \\
7 & $\begin{array}{l}\text { Fonsumption } \\
\text { Investment }\end{array}$ & FDI & $\begin{array}{l}\text { Foreign Direct Investment inflow as percentage of } \\
\text { GDP and retrieved from 2018 updated WDI }\end{array}$ \\
$\begin{array}{l}\text { Renewable } \\
\text { energy } \\
\text { consumption }\end{array}$ & R.E & $\begin{array}{l}\text { Renewable energy consumption in natural log and } \\
\text { retrieved from 2018 updated WDI }\end{array}$ \\
\hline
\end{tabular}

315 Source: Authors' construction
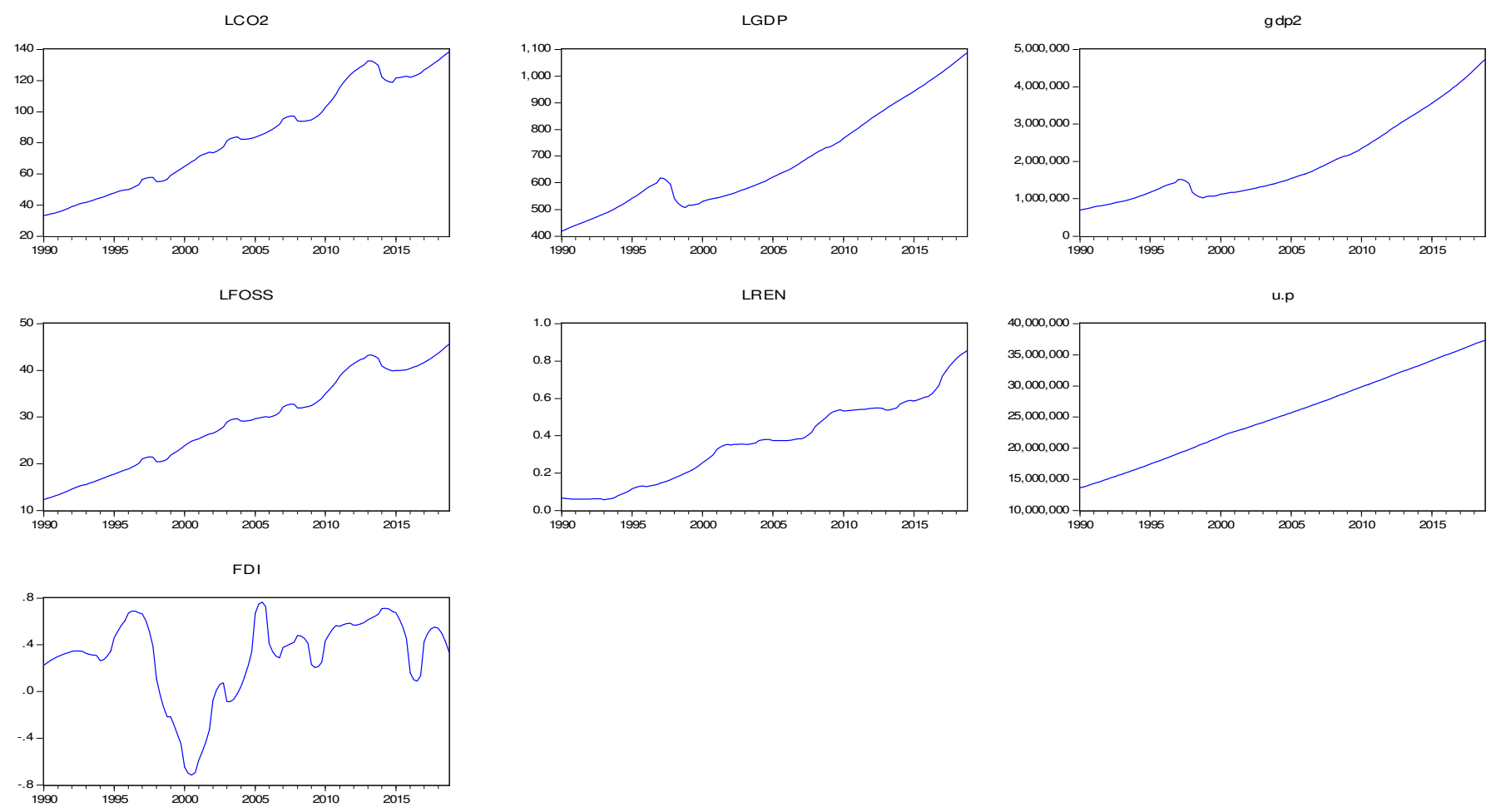

317 Figure 1: Trends of the instruments as displayed

318 Source: Authors' computations

319 Methodologies adopted in our study include summary and descriptive statistics, stationarity tests

320 with conventional and structural break approaches, autoregressive distributed lag (ARDL)-bound

321 tests and granger causality estimates. Diagnostic test is part of the analysis which is done with

322 serial and auto correlation tests, heteroscedasticity test and Cumulative sum and cumulative sum

323 square tests. Application of descriptive statistics helps in determining the normal distribution of

324 the data with both Jarque-Bera, skewness and kurtosis. The stationarity test is applied for the

325 determination of the order of the integration among the series. Conventional applications

326 (augmented dickey fuller, ADF, 1979; Philp-Perron, 1990 and Kwiatkowski-Phillips-Schmidt- 
Shin, KPSS, 1992) of stationarity tests are applied with Zivot Andrew (1992), structural break estimate to test for the unit root and the order of integration among the series. Most times, the structural shock in form of macroeconomic policies or natural events (Adedoyin et al., (2020) may constitute stationarity of the series when tested with conventional approaches, but when structural break test is applied, it will unveil the real unit root of the series. We applied ARDL -bound test for the estimation of cointegration. Granger causality is estimated with pairwise granger causality method.

\section{Empirical results and discussion}

\subsection{Descriptive statistics}

Normal distribution of the statistics utilized in this study is done with descriptive statistics. Result of the descriptive statistics with respect to Jarque-Bera and Kurtosis confirmed that the data are normally distributed with the values of the kurtosis fall below 3 except for the case of FDI.

Table 2: Descriptive statistics

\begin{tabular}{lcclcccc}
\hline Variables & LCO2 & LGDP & LGDP $^{2}$ & LFOSS & LREN & LU_P & FDI \\
\hline Mean & 83.87 & 680.10 & 1992 & 28.98 & 0.365 & 2528 & 0.299 \\
Median & 83.20 & 615.0 & 1511 & 29.46 & 0.375 & 2520 & 0.348 \\
Maximum & 138.5 & 1087. & 4727 & 45.59 & 0.854 & 3734 & 0.768 \\
Minimum & 33.15 & 418.7 & 7011 & 12.34 & 0.057 & 1361 & -0.716 \\
Std. Dev. & 32.41 & 185.8 & 1106 & 9.905 & 0.219 & 6954 & 0.352 \\
Skewness & 0.084 & 0.635 & 0.924 & -0.012 & 0.192 & 0.018 & -1.190 \\
Kurtosis & 1.684 & 2.183 & 2.637 & 1.737 & 2.115 & 1.818 & 3.940 \\
& & & & & & & \\
Jarque-Bera & 8.503 & 11.02 & 17.15 & 7.713 & 4.503 & 6.759 & 31.67 \\
Probability & 0.014 & 0.004 & 0.0002 & 0.021 & 0.105 & 0.034 & 0.000 \\
& & & & & & & \\
Sum & 9729. & 7899 & $2.31 \mathrm{E}+08$ & 3361. & 42.37 & $2.93 \mathrm{E}+09$ & 34.78 \\
Sum Sq. Dev. & 1208 & 3972 & $1.41 \mathrm{E}+14$ & 1128 & 5.505 & $5.56 \mathrm{E}+15$ & 14.18 \\
& & & & & & & \\
Observations & 116 & 116 & 116 & 116 & 116 & 116 & 116 \\
\hline
\end{tabular}

Source: Authors' computation with Eviews

4.2 Stationarity test

Unit/stationarity test is performed with both conventional and structural break approaches as remarked from the methodology section. The output from the both approaches confirmed mixed order of integration among the series. This confirmed that stationarity of the instruments took place both at level $\mathrm{I}(0)$ and first difference $\mathrm{I}(1)$. Moving further, structural breaks are noticed in the following years: 2010q4 and 2013q2 for carbon emission and foss, 2000q2 and 2003q2 for FDI, 
1997q2 and 1997q3 for economic growth (GDP), 2013q2 and 2014q2 for renewable energy,

$3482000 q 2$ and 2001q1 for urban population. Looking at the structural break tests output, it is deduced

349 that the breaks took place from 1997q2 to 2014q2 and this is within the specified period (1990Q1-

350 2018Q4) chosen for this study. Considering the break dates and events related to the highlighted

351 date, it is obvious the stationarity of the variables could be tampered with. Among the events that

352 caused shock to most of the economies of the world are the financial shocks of 1997/8 and 2008/10

353 and these dates are reflected in our structural break tests for economic growth and fossil fuels

354 energy. Even physical assessment of the trend of the instruments as shown in Figure 1, it is

355 observed that breaks that left the Indonesian economy in a permanent shock took place within the

356 identified periods as reflects in the structural break outputs. Both the outputs of the structural break

357 tests and the conventional unit root tests are displayed in Tables 3 and 4.

358 Table 3: Stationarity test (ADF. PP and KPSS)

\begin{tabular}{|c|c|c|c|c|c|}
\hline \multirow[t]{2}{*}{ Variables } & \multicolumn{3}{|c|}{ @level } & \multicolumn{2}{|l|}{ @ $1^{\text {st }}$ Diff } \\
\hline & Intercept & $\begin{array}{l}\text { Intercept and } \\
\text { trend }\end{array}$ & Intercept & $\begin{array}{l}\text { Intercept and } \\
\text { trend }\end{array}$ & Order \\
\hline & & & $\mathrm{ADF}$ & & \\
\hline $\mathrm{LCO}_{2}$ & -0.272 & $-3.786 * *$ & $-3.324 * *$ & $-3.311 *$ & MIXED \\
\hline LY & 1.244 & -0.891 & -2.299 & -2.842 & MIXED \\
\hline LU.P & 0.396 & -2.356 & $-2.707 *$ & -2.655 & $\mathrm{I}(1)$ \\
\hline LFOSS & -0.359 & $-3.963 * *$ & $-3.156^{* *}$ & -3.127 & MIXED \\
\hline LR.E & 0.486 & $-3.457 * *$ & -2.105 & -2.265 & $\mathrm{I}(0)$ \\
\hline FDI & $-2.781 *$ & -2.974 & -2.471 & -2.456 & $\mathrm{I}(0)$ \\
\hline & & & $\mathrm{PP}$ & & \\
\hline $\mathrm{LCO}_{2}$ & -0.134 & -2.580 & $-4.821 * * *$ & $-4.806 * * *$ & $\mathrm{I}(1)$ \\
\hline LY & 1.702 & -0.481 & $-4.603 * * *$ & $-4.806 * * *$ & $\mathrm{I}(1)$ \\
\hline LU.P & 1.861 & -1.970 & $-3.491 * * *$ & $-3.613 * *$ & $\mathrm{I}(1)$ \\
\hline LFOSS & -0.381 & -2.538 & $-4.751 * * *$ & $-4.729 * * *$ & $\mathrm{I}(1)$ \\
\hline LR.E & 1.570 & -1.599 & $-3.902 * * *$ & $-4.149 * * *$ & $\mathrm{I}(1)$ \\
\hline FDI & -2.122 & -2.201 & $\begin{array}{l}-5.090 * * * \\
\text { KPSS }\end{array}$ & $-5.062 * * *$ & $\mathrm{I}(1)$ \\
\hline $\mathrm{LCO}_{2}$ & $1.254 * * *$ & 0.072 & 0.048 & 0.042 & $\mathrm{I}(1)$ \\
\hline LY & $1.179 * * *$ & $0.283 * * *$ & $0.415^{*}$ & 0.093 & MIXED \\
\hline LU.P & $1.266 * * *$ & $0.134 *$ & 0.318 & 0.084 & $\mathrm{I}(1)$ \\
\hline LFOSS & $1.255 * * *$ & 0.061 & 0.039 & 0.039 & $\mathrm{I}(1)$ \\
\hline LR.E & $1.250 * * *$ & 0.065 & 0.278 & 0.087 & $\mathrm{I}(1)$ \\
\hline FDI & 0.266 & $0.132 *$ & 0.054 & 0.054 & $\mathrm{I}(1)$ \\
\hline
\end{tabular}

359 Attn: Significant levels are represented with *,** and *** at 10\%, 5\% and $1 \%$.

360 Source: Authors' computation with Eviews

361

362

Table 4: Structural Break test (Zivot-Andrew) 


\begin{tabular}{lllllll}
\hline Variables & ZA & P-value & Lag & $\begin{array}{l}\text { Break } \\
\text { period }\end{array}$ & CV@ 1\% & CV@ 5\% \\
\hline LCO $_{2}$ & $-3.882 * * *$ & 0.008 & 4 & $2010 \mathrm{Q} 4$ & -5.57 & -508 \\
LY & $-8.085 * * *$ & 0.000 & 4 & $1997 \mathrm{Q} 3$ & -5.57 & -508 \\
LU.P & $-6.018^{* * *}$ & 0.000 & 4 & $2001 \mathrm{Q} 1$ & -5.57 & -508 \\
LFOSS & $-3.622 * *$ & 0.032 & 4 & $2010 \mathrm{Q} 4$ & -5.57 & -508 \\
LR.E & $-4.902 * * *$ & 0.007 & 4 & $2014 \mathrm{Q} 2$ & -5.57 & -508 \\
FDI & $-3.192 * * *$ & 0.003 & 4 & $2003 \mathrm{Q} 2$ & -5.57 & -508 \\
DLCO 2 & $-5.531 * * *$ & 0.000 & 4 & $2013 \mathrm{Q} 2$ & -5.57 & -508 \\
DLY & $-5.596 * * *$ & 0.001 & 4 & $1997 \mathrm{Q} 2$ & -5.57 & -508 \\
DLU.P & $-9.056 * * *$ & 0.000 & 4 & $2000 \mathrm{Q} 2$ & -5.57 & -508 \\
DLFOSS & $-5.085 * * *$ & 0.000 & 4 & $2013 \mathrm{Q} 2$ & -5.57 & -508 \\
DLR.E & $-3.840 * *$ & 0.050 & 4 & $2013 \mathrm{Q} 2$ & -5.57 & -508 \\
DFDI & $-5.267 * * *$ & 0.000 & 4 & $2000 \mathrm{2} 2$ & -5.57 & -508 \\
\hline Att Signifl
\end{tabular}

363 Attn: Significant levels are represented with *** and *** at 10\%, 5\% and 1\%.ZA=Zivot Andrew, 364 LG=lag, Prob.=Probability value, $\mathrm{CV}=$ critical values.

365 Source: Authors' computation with Eviews

\subsection{Cointegration and linear relationships}

367 Cointegration and dynamic analysis of the both the short run and long run relationship among the instruments are estimated with ARDL-bound test, and the result of the estimations are shown in the Table 5 below. Also, results of diagnostic tests ranging from auto and serial correlations to heteroscedasticity are all displayed in the Table 5. Firmness of the model is equally tested with cumulative sum and cumulative sum squared (CUSUM and CUSUM ${ }^{2}$ ) tests and the outputs are

372 placed under the Table 5 shown with Figures 2 and 3. The preliminary test confirmed the goodness 373 of fit of the adopted model with the values of $\mathrm{R}^{2}=0.990$ and Adjusted $\mathrm{R}^{2}=0.987$. This suggests that 374 the environment indicator (carbon dioxide emission) which is the endogenous instrument $\left(\mathrm{CO}_{2}\right)$ 375 is explained by the exogenous variables (economic growth, Urban Population, Fossil fuels, 376 Renewable Energy and FDI) at 99 percent. The remaining part of the carbon emission is explained 377 by the error term. Our model shows ability to correct any short run disequilibrium in the long run 378 with negative coefficient (-0.112) of the error correction model (ECM) at 1 percent significant 379 level. This points to the correction of the short run disequilibrium at 11.2 percent in the long run, 380 that is 8.9 years for the adjustment ( 1 divided by the coefficient of the ECM). Also, there is 381 possibility of existence of long run relationship among the selected variables of this study. Absence 382 of heteroscedasticity, auto and serial correlation are established with the outputs of their respective 383 tests, hence, for Heteroscedasticity, Breusch-Pagan-Godfrey tests shows F-stats and Chi-square at 3841.220 [0.231] and 43.49 [0.249], for serial correlation, F-stats and Chi-square at 0.514[0.60] and 
1.605[0.45] respectively. Durbin Watson value at 1.8 rules out the presence of autocorrelation from the model. Further check on the stability of the model was done with cumulative sum and cumulative sum square (CUSUM and CUSUM ${ }^{2}$ ) and the output is displayed with Figures 2 and 3 below Table 5. Lag selection is sensitive in this estimation and hence was performed with Akaike Information Criterion (AIC) and 5 was considered the appropriate lag for this estimation. The result will be available on request. Cointegration was confirmed in this estimation with F-stats from ARDL-bound test greater than the critical values of upper bound at 12.88 and 3.77. Going further in this analysis, we present and explain the findings of dynamic relationships between the instrument in both periods (short term and long term estimates). The conclusion and policy recommendation will be majorly built on these findings. From both short run and long run we find negative and positive coefficients of LY and $\mathrm{LY}^{2}$ which established negative connection between economic growth ( $\mathrm{LY}=\mathrm{GDP})$ and environment $\left(\mathrm{LCO}_{2}\right)$, and positive relationship between squared economic growth $\left(\mathrm{LY}^{2}=\mathrm{GDP}^{2}\right)$ and environment $\left(\mathrm{LCO}_{2}\right)$. Hence, the findings from both short run and long run attest to the U-shaped association between income (GDP) growth and environmental performance. This means that EKC is does not exist in the case of Indonesia. Statistically, a percentage rise in income growth (real GDP) will cause a drop of carbon emissions $\left(\mathrm{LCO}_{2}\right)$ by 0.134 percent in both periods. In the case of squared real GDP, coefficient with a positive sign denotes carbon emission increasing as economic growth is increasing confirming a break-out of the initial decreasing relationship at the peak level of income (real GDP). This aligns with the findings of Wijayanti, et al., (2018) for Indonesia; Hossain, (2012) for Japan; Ang, (2008) for Malaysia; Bekhet et al., (2014) for UAE and Saudi Arabia. However, our finding contradict the findings by Sugiawan and Managi, (2016) for Indonesia. Both the short run and long run elasticity of carbon emissions $\left(\mathrm{LCO}_{2}\right)$ with respect to urbanization (urban population) is -2.12E-05 (0.00000212) for the case of Indonesia. This is supposes that a percent increase in urbanization will lead to 2.12E-05 decrease of Indonesian per capita carbon emission. This is an indication that there is high sensitization and increase awareness of clean in environment in Indonesian Cities. It is equally a pointer that literacy rate is high in the country's urban areas. It could equally mean that technological innovation and clean energy mix (renewable energy sources) in economic operations in the cities is at increasing rate. This suggests that carbon neutrality could be attained through urbanization. This findings supports the findings from Ahmed et al., (2019) for Indonesia but contradicts the finding from Kurniawan and Managi, (2018). This could be because of difference 
416 in indicators of measuring environment in both studies. The short run and long run elasticities of 417 carbon emission (LCO2) with respect to non-renewable energy source (fossil fuels) is 3.681 418 respectively. This shows that a percentage increase in fossil fuels utilization will increase carbon 419 emission by 3.7 percent thereby degrading the Indonesian environmental. This suggests the 420 negative implication of fossil fuel based energy consumption on Indonesian environmental 421 development. Many literature (Udemba et al., 2019 for Indonesia; Udemba et al., 2021 for India; 422 Udemba, 2020 for Nigeria; Alola et al., (2021); Alola and Saint Akadiri, (2021) have found same 423 result both in the case of Indonesia and other countries. Going further, we find negative 424 relationships between renewable energy, FDI and carbon emission. This suggests that both clean 425 energy sources (renewable energy source) and FDI are mitigating the carbon emission increase in 426 Indonesia. This is a good story for Indonesia which points towards carbon neutrality in the country. 427 This shows that foreign investors in Indonesia are operating with consciousness of securing a good 428 environment performance. It equally shows the positive impact of energy transition on Indonesia 429 environment performance. Statistically, both short run and long run elasticities of carbon emission 430 with respect to renewable energy and FDI are -22.90 and -2.165 respectively. That is, a percentage 431 increase in renewable energy and FDI will decrease carbon emissions by 22.9 and 2.165 percent 432 respectively. The findings from both renewable energy and FDI for the case of Indonesia are really 433 interesting and are cable of attaining some level of carbon neutrality in the country. This findings 434 support the finding from Udemba et al., 2019 for Indonesia; Haug and Ucal (2019); Sarkodie and 435 Strezov (2019); Shahbaz et al 2019; Atici , (2012). The entire findings from both ARDL short run 436 and long run dynamics points towards carbon neutrality in Indonesia, hence, three instruments 437 (urbanization, FDI and renewable energy use) adopted in this study point towards their ability to 438 mitigate carbon emission increase in the country. This is a positive trend and a good platform for 439 the policy makers in the country to pursue United Nation sustainable development goal (SDGs).

440 Table 5: Cointegration (ARDL-bound test), Short run and Long run linear relationships

\begin{tabular}{llllllll}
\hline Variables & Coef & SE & T-stats & Variables & Coef & SE & T-stats \\
\hline & Short-run & & & & Long-run & & -0.974 \\
DLY & -0.134 & 0.085 & -1.566 & LY & -0.134 & 0.1371 & 0.945 \\
DLY & $2.83 E-05$ & $1.86 E-05$ & 1.519 & LY & $2.83 E-05$ & $3.00 E-05$ & $0.95 *$ E \\
DLU.P & $-2.12 E-05$ & $1.76 E-06$ & $-12.04 * * *$ & LU.P & $-2.12 E-05$ & $2.42 E-06$ & $-8.742 * * *$ \\
DLFOSS & 3.681 & 0.086 & $42.98 * * *$ & LFOSS & 3.681 & 0.114 & $32.34 * * *$ \\
DLR.E & -22.90 & 5.483 & $-4.177 * * *$ & LR.E & -22.90 & 7.327 & $-3.126 * * *$ \\
DFDI & -2.165 & 0.364 & $-5.952 * * *$ & FDI & -2.165 & 0.476 & $-4.549 * * *$ \\
CointEq(-1) & -0.112 & 0.009 & $-12.04 * * *$ & C & 2.940 & 0.903 & $3.258 * * *$ \\
\hline
\end{tabular}




\begin{tabular}{|c|c|c|c|c|}
\hline $\mathrm{R}^{2}$ & 0.990 & & & \\
\hline Adj $R^{2}$ & 0.987 & & & \\
\hline D.Watson & 1.844 & & & \\
\hline Wald test & F-stats $=92917$ & $\begin{array}{l}\mathrm{P}- \\
\mathrm{v}=0.000\end{array}$ & & \\
\hline $\begin{array}{l}\text { Bound- } \\
\text { Coint. test }\end{array}$ & F-stats $=12.88$ & $\begin{array}{l}\mathrm{K}=8, @ 1 \\
\%\end{array}$ & $\mathrm{I}(0)=2.62$ & $\mathrm{I}(1)=3.77$ \\
\hline $\begin{array}{ll}\text { LM } & \text { Serial } \\
\text { test } & \end{array}$ & F-stats $=0.514$ & $\mathrm{R}^{2}=1.605$ & {$[0.60][0.45]$} & \\
\hline Heteros.test & F-stats $=1.220$ & $\mathrm{R}^{2}=43.49$ & {$[0.23][0.25]$} & \\
\hline
\end{tabular}

Attn: $*$, ** and $* * *$ represent significant at $10 \%, 5 \%$ and $1 \%$ respectively. Numbers inside brackets

442 are the prob. Values of F-stats and Chi-square for serial correlation and heteroscedasticity

443 Source: Authors' computation with Eviews

$444 \quad 4.5$ Diagnostic tests

445 (CUSUM and CUSUM²)
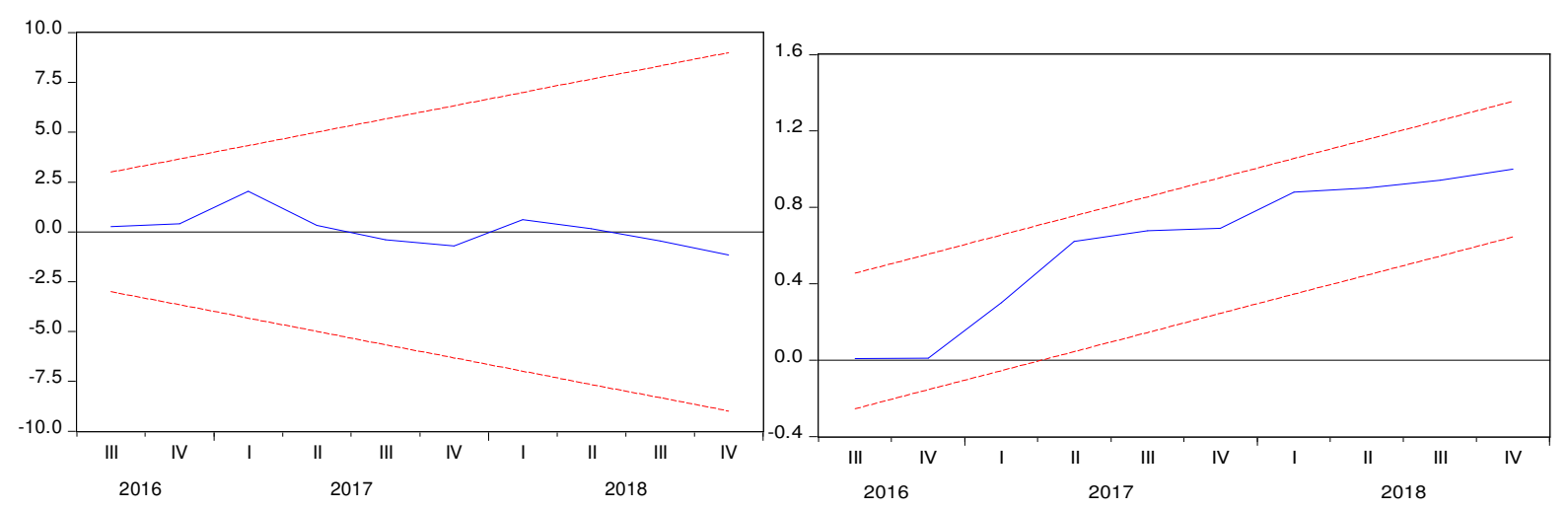

Figure 2: Test of stability of the model with Cumulative Sum of recursive residual Plot

Figure 3: Test of stability of the model with Cumulative Sum Squared of recursive residual Plot

Source: Authors' Computation with Eviews

4.6 Granger causality test

449 Granger causality is adopted in this study to expose the originator and the direction (i.e. 450 unidirectional or bidirectional) of the relationship that existed among the selected variable. It helps 451 to draw inference and in forecasting the future performance trend of the instruments. While, the 452 ARDL dynamics in both short run and long run are exposing the relationship that exist among the 453 variables with the rate of impact, granger causality gives insight on the instrument that is impacting 454 each other. The result of the pairwise granger causality is displayed in Table 6 below. From the 455 estimation we find uni-directional causality passing from economic growth to urbanization, from 
456 fossil fuels to urbanization, from renewables to urbanization, from FDI to fossil fuels and from 457 FDI to renewable energy. Moreover, we find bi-directional causality between urbanization and 458 carbon emission, between renewable energy and carbon emission, between renewable energy and 459 fossil fuels. The findings from granger causality give credence to the findings from the ARDL 460 dynamics among the variables in both periods. It gives great exposition on the stance of 461 urbanization, FDI and renewable energy source in determination of Indonesian environment.

462 Table 6: Pairwise Granger causality analysis

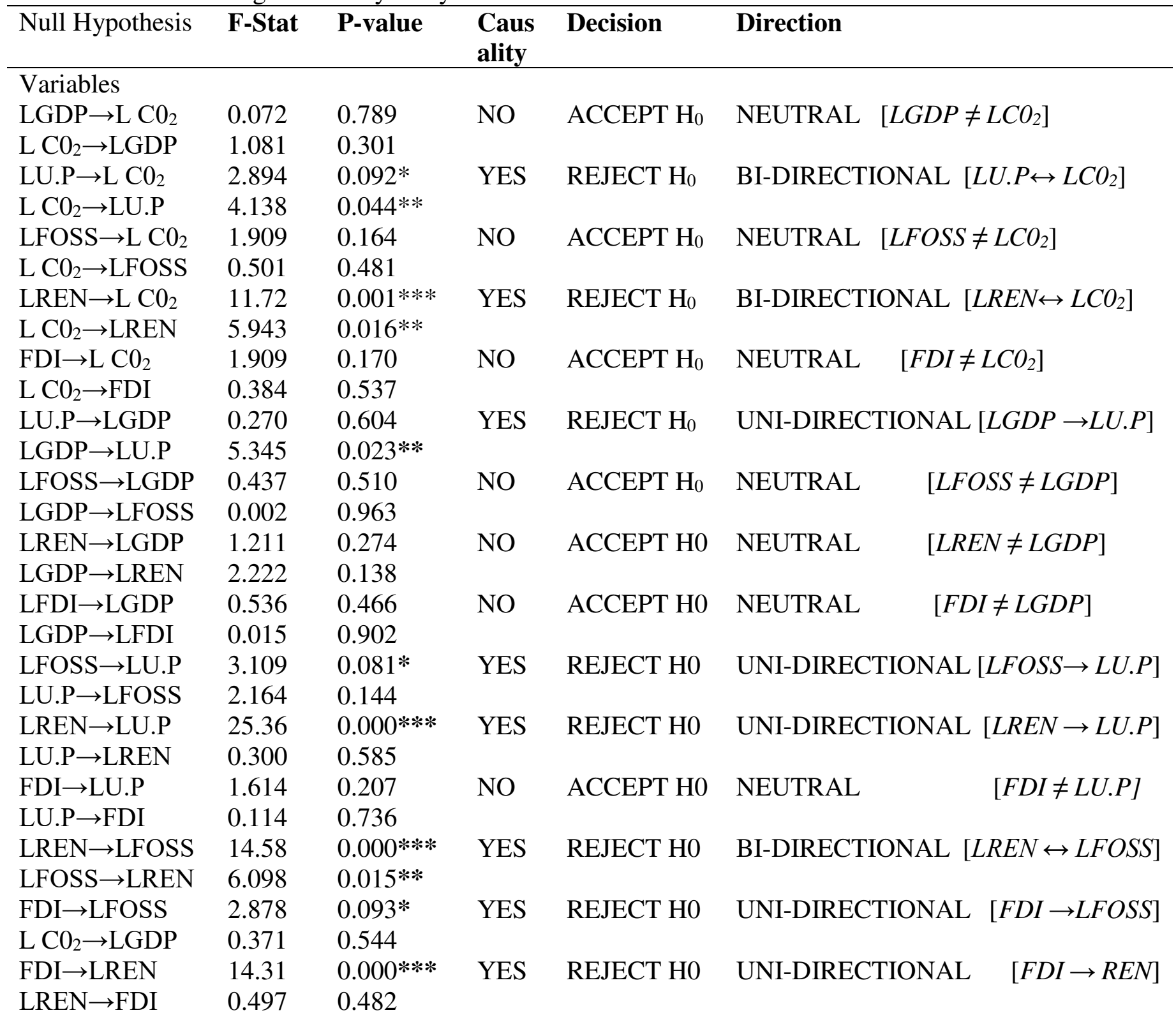

Note: The numbers inside bracket are the p-values of the parameters. The numbers that are written

464 in bold colors represent the parameters that are significant in the causal relationship among the 465 variables. Source: Authors' computation 


\section{Concluding remark and policy framing}

467 This study is targeted on assessing the ability of carbon neutrality in Indonesia through energy 468 transition (shift to renewable source of energy), FDI and urbanization policies. Indonesia is one of the largest and fastest growing economies in Southeast Asia. As noted before, Indonesia is positioned as among the best performing economies in Southeast Asia because of its vigorous fiscal management and sustained economic growth over the years. The country's foreign investment inflow increased to $14 \%$ in 2019 , largely in gas, electricity, water, and transportation because of the viability of its macroeconomic reforms. Some of the reforms are policies targeted to enhance growth in investment in the entire economy. Among the policies are tax incentives for investment in major economic sectors, law enforcement and business certainty, cuts in interest rate tax on exporters and energy tariffs for industries. Indonesian economy is positively overhauled and ranked 17th out of 20 top host countries based on the source of investment. As emerging country that is characterized with growth and investment potentials especially in the areas of gas, electricity, water, and transportation, there is likelihood of great utilization of energy sources which has potentials in impacting environment and climate change through greenhouse gas.

Against this backdrop, we select the macroeconomic and energy cum environment variables (real GDP per capita and its square, FDI, urbanization, fossil fuels and renewable energy source) to test the sustainable development of the country with respect to environment. We applied different approaches (structural break, ARDL-bound test and granger causality) with intent to expose the current state of Indonesian environment performance and its ability to mitigate carbon emission in a bid to foster carbon neutrality. Specifically, we considered the findings from ARDL and granger causality for this analysis and policy framing. From ARDL short run and long run dynamics we find interesting results pointing towards the ability of Indonesia to mitigate carbon emission (carbon neutrality) except in the case of fossil fuels. Hence, negative relationship is established between carbon emission and renewable energy source, FDI and urbanization. Also, a U-shape instead of inverted U-shape EKC is found confirming the impeding implication of Indonesian economic growth to its environmental performance if not checkmate. From granger causality analysis, all the variables are seen transmitting to urbanization in a one-way causal relationship. Also, FDI and renewable energy prove to be essential determinants of the country's environment development, hence, FDI is seen transmitting to both energy source (fossil fuels and renewables) 
relationship with both carbon emission and fossil fuels. This result has equally exposed the significant position of the three instruments (urbanization, FDI and renewable energy source) in Indonesia environment development, and this finding attest to the above findings from ARDL result.

The expository findings from both approaches are necessary platform for policy enactment towards achieving greater fit in carbon neutrality. Hence, focus should be geared towards sustainable performance of foreign investors. FDI is found impacting positive to the environment development, however, regulatory policies towards safeguarding the quality of the environment from the side of foreign investors should be formulated, implemented and monitored for maximum achievement and success. National policy should be framed towards energy transition as clean energy source (renewable sources) is seen having the greater percentage of mitigating the carbon emission in the country. Part of the national policies should include bringing the foreign investors to the agreement of adopting improved technologies and adopting cleaner energy sources for the safety of the environment. Also, from the findings, urban populace is contributing towards achieving carbon neutrality but the momentum needs to be preserved through intense awareness on the need to sustain the improved quality of Indonesia environment. Public transportation system should be top priority in a bid to discourage excessive private vehicles that may constitute environmental harm. Apart from this, efforts should be geared towards shifting from vehicles that run on fossil fuels to electric vehicles to curtail the rate of injecting gases (nitrogen oxide, carbon monoxide and Sulfur dioxide) into the environment. In a nutshell, strong institutions are encouraged in other to achieve effective execution of the proposed policies.

Conclusively, this study has implication to other Southeast Asian countries that may wish to adopt the findings for policy framing for the case of their countries. Again, our work has not close the door of future research into this topic for changes are bound to take place as time goes on, and variance in findings may occur due to structural or natural occurrences. For this, future studies are encouraged especially with other vital instruments such as institutional quality and democracy.

\section{Declarations}

\section{Ethics approval and consent to participate}


526 We, the authors are giving our ethical approval and consent for this paper to be published in your

527 Journal if found publishable

528 Consent to participate

529 We, the authors are giving our consent for participation in this paper to be published in your Journal

530 if found publishable

\section{Consent for publication}

532 We, the authors are giving our consent for this paper to be published in your Journal if found 533 publishable

534 Availability of data and materials

535 Data sources are outlined above in the table 1 and will be made available on demand

536 Competing interests

537 We, the authors hereby declare that there are no competing or conflicting interests on the paper

$538 \quad$ Funding

539 No funding is provided for this research

540 Author's contributions

541 The paper is written by the two authors named in the Title page. Hence, Lucy wrote the intro-

542 literature while Edmund wrote the methodology and conclusion with abstract.

543 Acknowledgements

544 This manuscript has not been submitted to any journal for publication, nor is under review at 545 another journal or other publishing venue

547 REFERENCES

548 Abdouli, M., \& Hammami, S. (2017). Economic growth, FDI inflows and their impact on the 549 environment: an empirical study for the MENA countries. Quality \& Quantity, 51(1), 121-146. 
Adedoyin, F., Ozturk, I., Abubakar, I., Kumeka, T., Folarin, O., \& Bekun, F. V. (2020). Structural breaks in $\mathrm{CO} 2$ emissions: Are they caused by climate change protests or other factors?. Journal of environmental management, 266, 110628.

Ahmad, F., Draz, M. U., \& Yang, S. C. (2018). Causality nexus of exports, FDI and economic growth of the ASEAN5 economies: evidence from panel data analysis. The Journal of International Trade \& Economic Development, 27(6), 685-700.

Ahmed, Z., Wang, Z., \& Ali, S. (2019). Investigating the non-linear relationship between urbanization and CO 2 emissions: An empirical analysis. Air Quality, Atmosphere \& Health, 12(8), 945-953

Ali, R., Bakhsh, K., \& Yasin, M. A. (2019). Impact of urbanization on CO2 emissions in emerging economy: evidence from Pakistan. Sustainable Cities and Society, 48, 101553.

Alola, A. A., \& Saint Akadiri, S. (2021). Clean energy development in the United States amidst augmented socioeconomic aspects and country-specific policies. Renewable Energy, 169, 221-230 Alola, A. A., Lasisi, T. T., Eluwole, K. K., \& Alola, U. V. (2021). Pollutant emission effect of tourism, real income, energy utilization, and urbanization in OECD countries: a panel quantile approach. Environmental Science and Pollution Research, 28(2), 1752-1761

Ang, J. B. (2008). "Economic development, pollutant emissions and energy consumption in Malaysia”, Journal of Policy Modeling , 30, 271-278.

Anwar, A., Younis, M., \& Ullah, I. (2020). Impact of urbanization and economic growth on CO2 emission: A case of far east Asian countries. International journal of environmental research and public health, 17(7), 2531.

Atici, C. (2012). Carbon emissions, trade liberalization, and the Japan-ASEAN interaction: A group-wise examination. Journal of the Japanese and International Economies, 26(1), 167-178.

Atici, C. (2012). Carbon emissions, trade liberalization, and the Japan-ASEAN interaction: A group-wise examination. Journal of the Japanese and International Economies, 26(1), 167-178.

Bachri, A. A., \& Normelani, E. (2020). FDI, Income, and Environmental Pollution in Indonesia. International Journal of Energy Economics and Policy, 10(6), 383.

Bekhet, H. A., El-Refae, G., \& Yasmin, T. (2014). Comparative Study of Environmental Kuznets Curve and Co-integration between Saudi Arabia and UAE Economies: Time Series Analysis.

Dickey DA, Fuller WA (1979) Distribution of the estimators for autoregressive time series with a unit root. J Am Stat Assoc 74(366a):427-431

Dietz, T., \& Rosa, E. A. (1994). Rethinking the environmental impacts of population, affluence and technology. Human Ecology Review, 1(2), 277-300.

Effendi, N., \& Soemantri, F. M. (2003, July). Foreign direct investment and regional economic growth in Indonesia: A panel data study. In The 6TH IRSA INTERNATIONAL CONFERENCE, 
Regional Development in The Era of Decentralization: Growth, Poverty, and Environment, Bandung.

Ehrlich, P., \& Holdren, J. (1970). The people problem. Saturday Review, 4 (42), 42-43.

Guo, M., Hu, Y., \& Yu, J. (2019). The role of financial development in the process of climate change: evidence from different panel models in China. Atmospheric Pollution Research, 10(5), 1375-1382.

Harrison, P. (1994). The third revolution: Population, environment and a sustainable world. Canadian Journal of Development Studies, 15, 291.

Haug, A. A., \& Ucal, M. (2019). The role of trade and FDI for CO2 emissions in Turkey: Nonlinear relationships. Energy Economics, 81, 297-307.

Haug, AA, \& Ucal, M. (2019). The role of trade and FDI for CO2 emissions in Turkey: Nonlinear relationships. Energy Economics, 81, 297-307.

Hossain, S. (2012). "An econometric analysis for CO2 emissions, energy consumption, economic growth, foreign trade and urbanization of Japan”, Low Carbon Economy, 3, 92-105.

https://unctad.org/news/global-foreign-direct-investment-fell-42-2020-outlook-remains-weak

https://www.irena.org//media/Files/IRENA/Agency/Publication/2017/Mar/IRENA_REmap_Indo nesia_report_2017.pdf?la=en\&hash=79237811C02D9722E35F5049ACBA278B126493BB

Hübler, M., \& Keller, A. (2010). Energy savings via FDI? Empirical evidence from developing countries. Environment and Development economics, 59-80.

Javorcik, B. S., \& Spatareanu, M. (2008). To share or not to share: Does local participation matter for spillovers from foreign direct investment?. Journal of development Economics, 85(1-2), 194217.

Jun, W., Zakaria, M., Shahzad, S. J. H., \& Mahmood, H. (2018). Effect of FDI on pollution in China: New insights based on wavelet approach. Sustainability, 10(11), 3859.

Katircioglu, S. (2009). Foreign direct investment and economic growth in Turkey: an empirical investigation by the bounds test for co-integration and causality tests. Economic researchEkonomska istraživanja, 22(3), 1-9.

Keller, W. (2004). International technology diffusion. Journal of economic literature, 42(3), 752782.

Kersan-Škabić, I., \& Zubin, C. (2009). The influence of foreign direct investment on the growth of GDP, on employment and on export in Croatia. Ekonomski pregled, 60(3-4), 119-151.

Khaliq, A., \& Noy, I. (2007). Foreign direct investment and economic growth: Empirical evidence from sectoral data in Indonesia. Journal of Economic Literature, 45(1), 313-325. 
618

619

620

621

622

623

624

625

626

627

628

629

630

631

632

633

634

635

636

637

638

639

640

641

642

643

644

645

646

647

648

649

650

651

652

Kurniawan, R., \& Managi, S. (2018). Coal consumption, urbanization, and trade openness linkage in Indonesia. Energy Policy, 121, 576-583.

Kusumadewi, T. V., \& Limmeechokchai, B. (2017). CO2 mitigation in residential sector in Indonesia and Thailand: potential of renewable energy and energy efficiency. Energy Procedia, $138,955-960$.

Kuznets, S. (1955). Economic growth and income inequality. The American Economic Review, $45(1), 1-28$.

Kwiatkowski D, Phillips PC, Schmidt P, Shin Y (1992) Testing the null hypothesis of stationarity against the alternative of a unit root. J Econ 54(1-3):159-178

Mahmoodi, M., \& Mahmoodi, E. (2016). Foreign direct investment, exports and economic growth: evidence from two panels of developing countries. Economic research-Ekonomska istraživanja, 29(1), 938-949.

Merican, Y., Yusop, Z., Noor, Z. M., \& Hook, L. S. (2007). Foreign direct investment and the pollution in five ASEAN nations. International Journal of Economics and Management, 1(2), 245261.

Öztürk, Z. \& Öz, D. (2016). The relationship between energy consumption, income, foreign direct investment, and CO2 emissions: the case of Turkey. Çankırı Karatekin University Journal of the Faculty of Economics and Administrative Sciences. 6(2), 269-288.

Perron P (1990) Testing for a unit root in a time series with a changing mean. J Bus Econ Stat $8(2): 153162$

Pesaran, M. H., Shin, Y., \& Smith, R. J. (2001). Bounds testing approaches to the analysis of level relationships. Journal of applied econometrics, 16(3), 289-326.

Philip, L. D., Sertoglu, K., Saint Akadiri, S., \& Olasehinde-Williams, G. Foreign direct investment amidst global economic downturn: is there a time-varying implication for environmental sustainability targets?. Environmental Science and Pollution Research, 1-10.

Qi, T., Zhang, X., \& Karplus, V. J. (2014). The energy and CO2 emissions impact of renewable energy development in China. Energy Policy, 68, 60-69.

Rosa, E. A., \& Dietz, T. (1998). Climate change and society: Speculation, construction and scientific investigation. International Sociology, 13(4),421-455.

Sarkodie, S. A., \& Strezov, V. (2019). Effect of foreign direct investments, economic development and energy consumption on greenhouse gas emissions in developing countries. Science of the Total Environment, 646, 862-871.

Sarkodie, S. A., \& Strezov, V. (2019). Effect of foreign direct investments, economic development and energy consumption on greenhouse gas emissions in developing countries. Science of the Total Environment, 646, 862-871. 
Sebri, M., \& Ben-Salha, O. (2014). On the causal dynamics between economic growth, renewable energy consumption, $\mathrm{CO} 2$ emissions and trade openness: Fresh evidence from BRICS countries. Renewable and Sustainable Energy Reviews, 39, 14-23.

Shahbaz, M., Balsalobre-Lorente, D., \& Sinha, A. (2019). Foreign direct Investment-CO2 emissions nexus in Middle East and North African countries: Importance of biomass energy consumption. Journal of cleaner production, 217, 603-614.

Shezan, S. K. A., Al-Mamoon, A., \& Ping, H. W. (2018). Performance investigation of an advanced hybrid renewable energy system in Indonesia. Environmental Progress \& Sustainable Energy, 37(4), 1424-1432.

Sjöholm, F. (2017). Foreign 10 direct investment and value added in Indonesia1. The Indonesian Economy: Trade and Industrial Policies, 238.

Sugiawan and Managi, (2016). The environmental Kuznets curve in Indonesia: Exploring the potential of renewable energy. Energy Policy, 98, 187-198 for Indonesia

Sugiawan, Y., \& Managi, S. (2016). The environmental Kuznets curve in Indonesia: Exploring the potential of renewable energy. Energy Policy, 98, 187-198.

Udemba, E. N. (2019). Triangular nexus between foreign direct investment, international tourism, and energy consumption in the Chinese economy: accounting for environmental quality. Environmental Science and Pollution Research, 26(24), 24819-24830.

Udemba, E. N. (2020). A sustainable study of economic growth and development amidst ecological footprint: New insight from Nigerian Perspective. Science of the Total Environment, $732,139270$.

Udemba, E. N., Güngör, H., \& Bekun, F. V. (2019). Environmental implication of offshore economic activities in Indonesia: a dual analyses of cointegration and causality. Environmental Science and Pollution Research, 26(31), 32460-32475.

Udemba, E. N., Güngör, H., Bekun, F. V., \& Kirikkaleli, D. (2021). Economic performance of India amidst high CO2 emissions. Sustainable Production and Consumption, 27, 52-60.

Wijayanti, D. L., \& Sugiyanto, F. X. (2018). Causality Gross Domestic Product (GDP) and Air Pollution. An Overview of Environment Kuznets Curve (EKC) Case: Indonesia. Advanced Science Letters, 24(5), 3031-3037

York, R., Rosa, E. A., \& Dietz, T. (2003a). Footprints on the earth: The environmental consequences of modernity. American Sociological Review,68, 279-300.

York, R., Rosa, E. A., \& Dietz, T. (2003b). STIRPAT, IPAT and ImPACT: Analytic tools for unpacking the driving forces of environmental impacts. Ecological Economics, 46(3), 351-365.

Zhang, S., \& Zhao, T. (2019). Identifying major influencing factors of CO2 emissions in China: regional disparities analysis based on STIRPAT model from 1996 to 2015. Atmospheric Environment, 207, 136-147. 
689 Zivot EA,DWK Andrews (1992) Further evidence on the great crash, oil prices shock and the unit 690 root hypothesis. Journal of Business and Economics Statistics 10(3):251-270

691 